\title{
Article \\ On the Performance of a Sustainable Rice Husk Biochar for the Activation of Persulfate and the Degradation of Antibiotics
}

\author{
Efstathios Avramiotis ${ }^{1}\left(\mathbb{D}\right.$, Zacharias Frontistis ${ }^{2}\left(\mathbb{D}\right.$, Ioannis D. Manariotis ${ }^{3} \mathbb{D}$, John Vakros ${ }^{1, *}$ \\ and Dionissios Mantzavinos ${ }^{1}$ (D)
}

1 Department of Chemical Engineering, University of Patras, Caratheodory 1, GR-26504 Patras, Greece; e.avramiotis@upatras.gr (E.A.); mantzavinos@chemeng.upatras.gr (D.M.)

2 Department of Chemical Engineering, University of Western Macedonia, GR-50100 Kozani, Greece; zfrontistis@uowm.gr

3 Environmental Engineering Laboratory, Department of Civil Engineering, University of Patras, GR-26504 Patras, Greece; idman@upatras.gr

* Correspondence: vakros@chemistry.upatras.gr

Citation: Avramiotis, E.; Frontistis, Z.; Manariotis, I.D.; Vakros, J.; Mantzavinos, D. On the Performance of a Sustainable Rice Husk Biochar for the Activation of Persulfate and the Degradation of Antibiotics. Catalysts 2021, 11, 1303. https:// doi.org/10.3390/catal11111303

Academic Editor: Atsushi Takagaki

Received: 12 October 2021

Accepted: 27 October 2021

Published: 28 October 202

Publisher's Note: MDPI stays neutral with regard to jurisdictional claims in published maps and institutional affiliations.

Copyright: (c) 2021 by the authors. Licensee MDPI, Basel, Switzerland. This article is an open access article distributed under the terms and conditions of the Creative Commons Attribution (CC BY) license (https:// creativecommons.org/licenses/by/ $4.0 /)$.

\begin{abstract}
Sulfate-radical-based advanced oxidation processes are highly effective in the degradation of antibiotics in water and wastewater. The activation of sulfate radicals occurs with the use of biochar, a low-cost carbon material. In this work, the preparation of biochar from rice husk for the degradation of various antibiotics was studied, and the biochar was compared with another biochar prepared at a different pyrolysis temperature. The biochar was prepared at $700{ }^{\circ} \mathrm{C}$ under limited $\mathrm{O}_{2}$. It had a high specific surface area of $231 \mathrm{~m}^{2} \mathrm{~g}^{-1}$ with micropores, a point of zero charge equal to 7.4 and a high silica content. The effect of different operating conditions on the degradation of organic compounds was studied. Increases in biochar dosage and sodium persulfate concentration were found to be beneficial for the degradation. In contrast, an increase in antibiotic concentration, the complexity of the water matrix and the existence of radical scavengers all had a detrimental effect on the activity. The comparison of the results with those from a biochar prepared at a higher temperature $\left(850^{\circ} \mathrm{C}\right)$ revealed that the preparation conditions affect the performance. The biochar pyrolyzed at $700{ }^{\circ} \mathrm{C}$ exhibited different behavior from that prepared at $850{ }^{\circ} \mathrm{C}$, demonstrating the importance of the preparation route. The studied reaction was surface-sensitive and followed radical and non-radical pathways. The adsorption of the organic contaminant also played a significant role. The carbon phase characteristics determined the dominant pathway, which was radical formation, in contrast with the biochar prepared at higher temperature, where the degradation followed mainly non-radical pathways.
\end{abstract}

Keywords: rice husk; biochar; sodium persulfate; advanced oxidation processes; wastewater

\section{Introduction}

The valorization of biomass has been receiving increasing attention in recent decades because (i) it presents a viable waste management solution and (ii) it offers raw materials at a reduced cost [1]. Rice husk $(\mathrm{RH})$ valorization has been carried out in various ways including fuel and electricity/heat production and industrial and agricultural uses. Industrial uses include the production of chemicals, construction materials and biochars [2]. Biochars (BCs) were initially known as fertilizers or fuels, but in recent years they have been used in many applications, such as adsorbent materials [3-5], supercapacitors [6,7], catalysts or supports for catalysts [8], etc. An interesting application is the use of BCs as activators of oxidizing agents such as persulfate [9-12]. A review on persulfates activation by functional biochars for the removal of organic contaminants was recently published [13].

Rice is the third most commonly produced crop worldwide [14] and given that RH makes up at least $20 \%$ of the total weight of the raw crop (about $1.5 \times 10^{11} \mathrm{~kg}$ annually), this constitutes a significant waste requiring serious consideration [15]. Rice is also an abundant 
crop in Greece, which produces the third-largest quantity of rice in the EU [16]. RH is a lignocellulosic biomass containing $19.2-24.4 \%$ lignin, $28.6-43.3 \%$ cellulose, $22.0-29.7 \%$ hemicellulose and $17-20 \%$ ash [17]. Thus, rice husk biochar (RHB) is promising for use as a persulfate activator, since biochars produced from cellulose-rich biomass are known to outperform those produced from lignin-rich biomass [18].

Biochars have been used in numerous cases, on an experimental level, as activators of persulfate for the oxidation of antibiotics in water matrices [11,19]. This research is necessary because of the increasing frequency of detection of commonly used antibiotics in wastewater treatment plants (WWTPs) [20], as well as in fresh waters [21], e.g., up to about $0.5 \mathrm{mg} \mathrm{L}^{-1}$ in Huangpu River, China [22]. Antibiotics cannot fully degrade in WWTPs and when released into aquatic environments through livestock and production plants, they are considered to contribute to the development of antibiotic resistance, which threatens the prevention and treatment of various illnesses [23]. Sulfamethoxazole (SMX) was found in surface waters at concentrations up to $54 \mu \mathrm{g} \mathrm{L}^{-1}$ in Africa and up to $20 \mu \mathrm{g} \mathrm{L} \mathrm{L}^{-1}$ in Asia and the USA, while ampicillin (AMP) was detected at concentrations up to $5.5 \mu \mathrm{g} \mathrm{L}^{-1}$ and norfloxacin (NOR) at concentrations up to $6.1 \mu \mathrm{g} \mathrm{L}^{-1}$ [22]. SMX is the most frequently detected antibiotic and the ninth in terms of concentration, while NOR is the fourth most frequently detected antibiotic and the second in terms of concentration [24]. No significant risk for mankind and the aquatic environment has been proved to exist due to the presence of SMX in water bodies, in most cases. On the other hand, antibiotic resistance could not be integrated into this risk assessment, and some cases do indicate a potential risk, demonstrating the need for further work [25]. The SMX molecule includes, among other things, an aromatic ring, an amino group, and the sulfonamide group [26], and it is mildly acidic $\left(\mathrm{pK}_{\mathrm{a}}=5.74\right)$ [27]. Its isoelectric point was found to be 4.5. Usually, it is found in neutral form with a $\mathrm{pH}$ between 1.4 and 5.8 , while it is negatively charged at higher $\mathrm{pH}$ values [28].

In recent years, advanced oxidation processes (AOPs) have gained attention for the degradation of antibiotics in watercourses, since biological treatment has been proven to be incapable of degrading them completely [20,29]. AOPs include ionizing radiation, Fenton, and Fenton-like reactions, ozonation, photocatalytic oxidation and electrochemical oxidation [30], The present study examines catalytic oxidation, since this can decompose the pollutants completely and avoid secondary pollution [31].

Sodium persulfate (SPS) is mainly used as an oxidizing agent because it has better characteristics than other oxidants and is more easily transportable and stable than $\mathrm{H}_{2} \mathrm{O}_{2}$, while sulfate radicals $\left(\mathrm{SO}_{4}{ }^{-}\right)$present an equal or higher redox potential, higher selectivity and a longer half-life compared to hydroxyl radicals $\left(\mathrm{OH}^{-}\right)$[32]. Sodium percarbonate $\left(\mathrm{Na}_{2} \mathrm{CO}_{3} \cdot 1.5 \mathrm{H}_{2} \mathrm{O}_{2}\right)$ can also be used as an oxidant since it releases $\mathrm{H}_{2} \mathrm{O}_{2}$ in water at a mild rate [33]. These radicals are produced effectively under catalytic activation of the appropriate oxidant. Interestingly, BC appears to be a suitable catalyst because it is a low-cost, stable and easily separable and reusable carbonaceous material that can activate persulfate, hydrogen peroxide [34] or sodium percarbonate [35] effectively for the degradation of organic contaminants. Biochars can be produced using any source of biomass and can be optimized by altering the production conditions [3]. Furthermore, they can retain their high catalytic reactivity when they are treated with persulfate ions [36].

Different mechanisms may occur for the activation of persulfate; the dominant ones are thought to occur through radical and singlet oxygen pathways [37]. Furthermore, an electron transfer pathway occurring through the carbon phase of the biochar has also been reported [26].

The use of RHB for the activation of persulfates and the degradation of organic contaminants, particularly antibiotics, has been reported in the literature. p-Nitrophenol was degraded by RHB-activated SPS, where the RHB was produced by pyrolysis at $400{ }^{\circ} \mathrm{C}$ for $1 \mathrm{~h}$ [9], and acid orange 7 has been degraded by RHB produced by pyrolysis at $700{ }^{\circ} \mathrm{C}$ for $2 \mathrm{~h} \mathrm{[38],} \mathrm{while} \mathrm{tetracycline} \mathrm{and} \mathrm{bisphenol} \mathrm{A} \mathrm{have} \mathrm{been} \mathrm{degraded} \mathrm{by} \mathrm{RHB-activated}$ peroxymonosulfate (PMS), where the RHB was produced by pyrolysis at $450{ }^{\circ} \mathrm{C}$ for $4 \mathrm{~h}$ [39]. 
The influence of pyrolysis temperature was investigated in a previous study by our research group [40]. RHB was prepared using four different temperatures and the produced materials were employed for the activation of SPS and the oxidation of SMX. It was found that the biochar prepared at $850{ }^{\circ} \mathrm{C}$ exhibited catalytic activity, while the oxidation mechanism followed non-radical pathways. In addition, the material prepared at $700{ }^{\circ} \mathrm{C}$ (denoted as RHB700 hereafter) still retained significant activity and required lower energy for production, while the physicochemical properties of the carbonaceous phase were substantially different from the biochar prepared at the higher temperature.

In this study, the structure and catalytic performance of RHB700 was studied in detail since lower pyrolysis temperatures minimize the catalyst's environmental footprint. This was achieved using various physicochemical characterizations and a complete examination of the factors that determine the oxidant activation (i.e., SPS, $\mathrm{H}_{2} \mathrm{O}_{2}$ and sodium percarbonate) and the degradation of the antibiotic (i.e., SMX, AMP and NOR, representing sulfonamides, $\beta$-lactams and fluoroquinolones, respectively). From the results of this study, we aimed to verify the capability of the RHB700 to degrade antibiotics, proposing it as a more sustainable biochar, and to evaluate the influence of the different physicochemical characteristics of RHB700 and RHB850 on the pathways of the oxidation process. The differences in the activity of the two biochars will help to determine the factors that are responsible for the activity, in order to prepare more active and selective biochars.

\section{Results and Discussion}

\subsection{Physicochemical Characterization}

Figure 1 shows representative SEM images of the RHB; significant amounts of minerals can clearly be seen, partly covering the organic phase. The organic phase is amorphous, while the inorganic phase can be either amorphous or crystalline, with crystallites of different dimensions. In accordance with the XRD and EDX results presented in the following paragraphs, the amorphous inorganic phase can be attributed to the silica content.
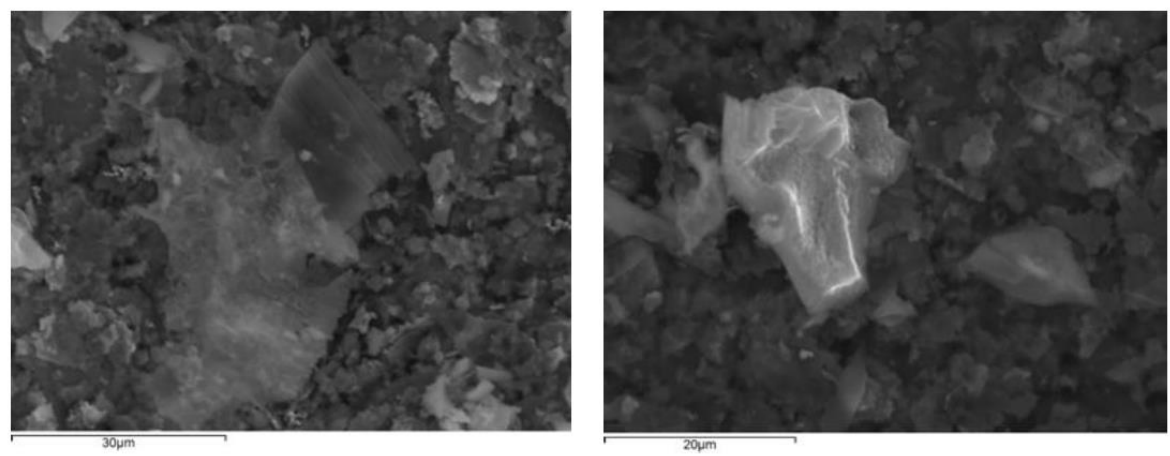

(a)

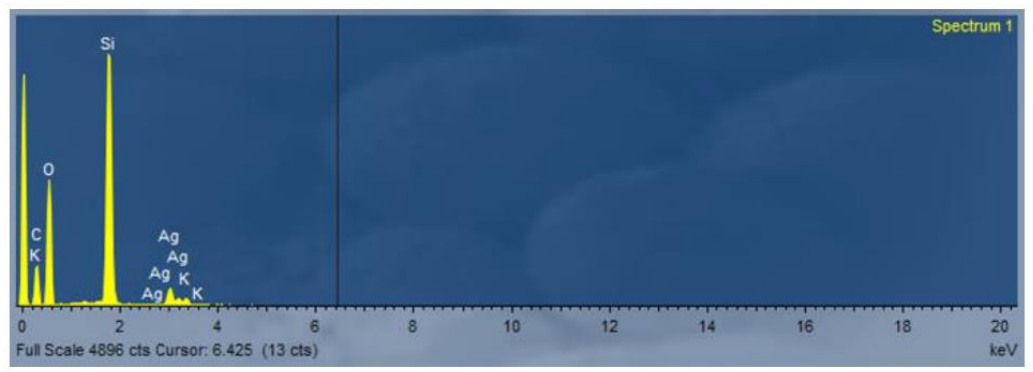

(b)

Figure 1. SEM images of RHB700 (a) and EDX analysis (b).

The energy-dispersive X-Ray (EDX) analysis showed that the biochar mainly consists of $\mathrm{C}$ and $\mathrm{O}$ with 66.5 and $28.5 \%$ atomic concentrations, respectively. The minerals detected were $\mathrm{Si}, \mathrm{Mg}$ and $\mathrm{K}$ with $4.86,0.04$ and $0.10 \%$ atomic surface concentrations, respectively. The results of the physicochemical characterizations are presented in Figure 2a-f. As can 
be seen from the thermogravimetric analysis in Figure 2a, the biochar begins to decompose at about $400{ }^{\circ} \mathrm{C}$ and the organic phase is totally burned at temperatures up to $550{ }^{\circ} \mathrm{C}$. Then, the mass remains constant and accounts for about $47 \%$ of the initial value. The carbon phase is less stable than the corresponding phase in the biochar prepared at $850{ }^{\circ} \mathrm{C}$ [40]. The carbonaceous phase is not homogenous, as revealed by the differential TG curve. There is a small shoulder centered at $440{ }^{\circ} \mathrm{C}$ and the main peak is at $512{ }^{\circ} \mathrm{C}$. This is evidence that either the carbonization at 700 is not enough for the complete degradation of the raw biomass or the biochar has significant heterogeneity and thus, several surface defects. According to the EDX analysis, there is significant content of Si. This is expected to be present as $\mathrm{SiO}_{2}$, which can explain the large amount of mass left after the TG run. The raw biomass contains a significant amount of $\mathrm{Si}$ and, as pyrolysis results in the removal of the organic phase and volatile inorganic species, the biochar is enriched in $\mathrm{SiO}_{2}$. The latter is in the amorphous phase since the characteristic peaks of quartz silica are not present [41] in the XRD pattern shown in Figure $2 \mathrm{~b}$. The figure exhibits a broad peak at about $22^{\circ}$, which is rather intense and symmetrical, and so could describe both the amorphous graphitic phase (peak corresponds to (002) crystal plane) and the amorphous silica phase. The main peak is accompanied by another broad peak, less intense and centered at about $43^{\circ}$. This peak can be detected in biochars and can be attributed to $C$ atoms with $\mathrm{sp}^{2}$ hybridization in the graphitic phase $[42,43]$.
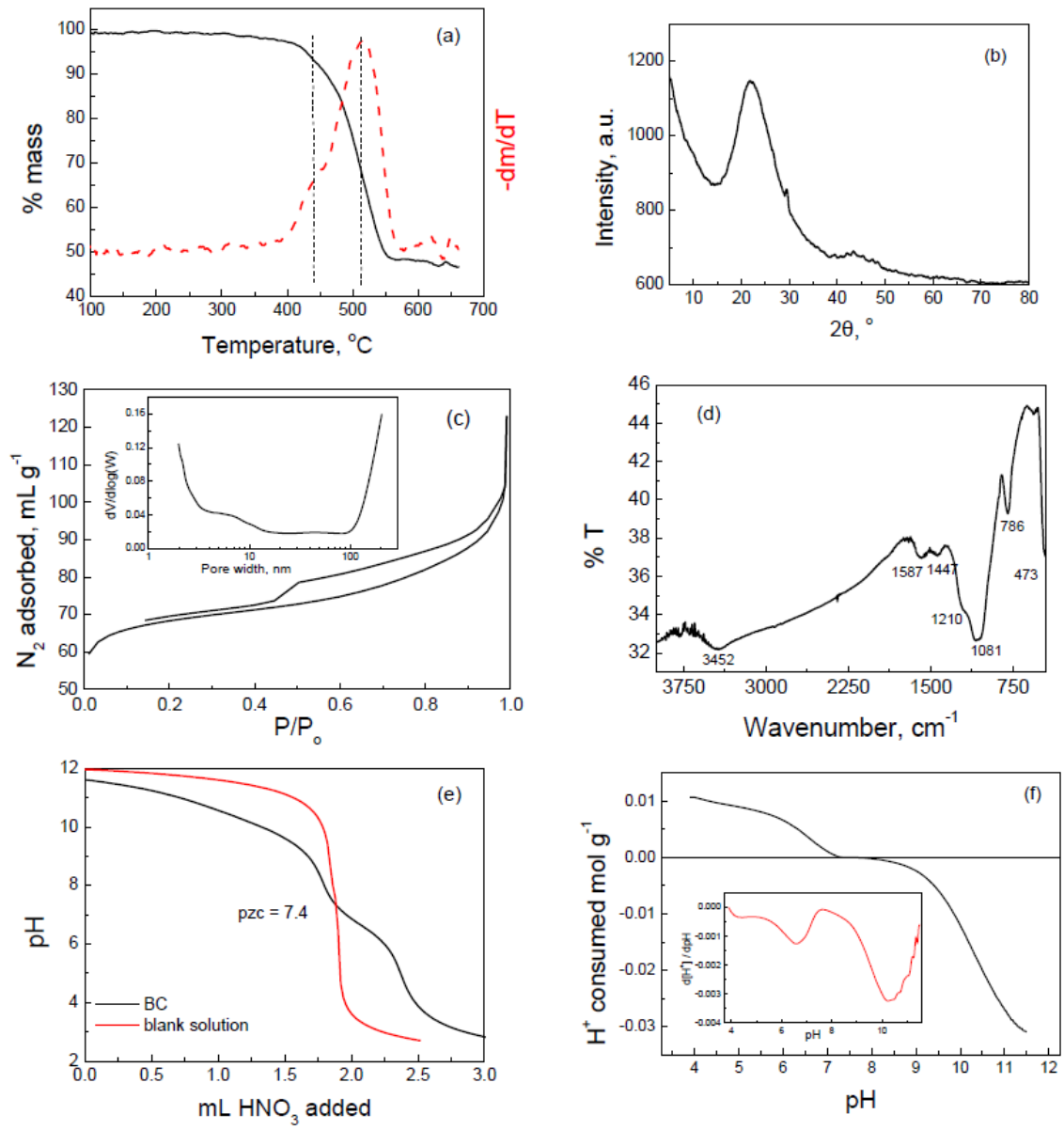

Figure 2. Physicochemical characterization of RHB700: (a) TGA curves under an air atmosphere with $20 \mathrm{~mL} \mathrm{~min}^{-1}$ flow and $10{ }^{\circ} \mathrm{C} \mathrm{min}^{-1}$ heating rate; (b) XRD pattern; (c) $\mathrm{N}_{2}$ adsorption-desorption isotherms with inset showing pore size distribution; (d) FTIR spectrum recorded in $1 \% \mathrm{w} / \mathrm{w}$ biochar in $\mathrm{KBr}$ pellet; (e) potentiometric mass titrations curve for the biochar and the corresponding curve for the blank solution; (f) the $\mathrm{H}^{+}$consumption by the surface as $\mathrm{pH}$ function with inset showing the differential curve of the $\mathrm{H}^{+}$consumed with $\mathrm{pH}$, where the inverse peaks denote the surface sites. 
The adsorption-desorption isotherm of $\mathrm{N}_{2}$ is presented in Figure 2c. From the high value of adsorbed $\mathrm{N}_{2}$ at low $\mathrm{P} / \mathrm{P}_{0}$ values, it can be seen that the biochar has a significant quantity of micropores [44,45]. The hysteresis loop observed between values of 0.3 and 0.95 of $\mathrm{P} / \mathrm{P}_{0}$ is related to the small quantity of mesopores [26].

The BET surface area of the biochar was $231 \mathrm{~m}^{2} \mathrm{~g}^{-1}, 177 \mathrm{~m}^{2} \mathrm{~g}^{-1}$ of which was due to the micropore surface area, as calculated by the t-plot method. The pore size distribution is presented in the inset of Figure $2 c$ and confirms the above findings. Finally, the pore volume is significant and equal to $0.15 \mathrm{~mL} \mathrm{~g}^{-1}$.

The biochar exhibits a significant quantity of surface groups as seen in the FTIR spectrum presented in Figure 2d. In accordance with the EDX results, there are-OH groups denoted by the broad peak centered at $3452 \mathrm{~cm}^{-1}$, the peak at $1081 \mathrm{~cm}^{-1}$ and a shoulder at $1210 \mathrm{~cm}^{-1}$, characteristic of the amorphous silica spectrum. These peaks are due to the formation of surface-OH groups, adsorbed water molecules and the formed $\mathrm{C}-\mathrm{OH}$ and $\mathrm{Si}-\mathrm{OH}$ bonds. The peaks at $786 \mathrm{~cm}^{-1}$ and $473 \mathrm{~cm}^{-1}$ are due to symmetric stretching and the $\mathrm{Si}-\mathrm{OH}$ bending mode, respectively [46,47]. Finally, the peaks at $1587 \mathrm{~cm}^{-1}$ and $1447 \mathrm{~cm}^{-1}$ are due to $\mathrm{C}=\mathrm{C}$ aromatic carbons. The aromatic phase is poor in $\mathrm{H}$ atoms since no peaks above $3000 \mathrm{~cm}^{-1}$ were detected.

The acid-base behavior of the biochar is presented in Figure 2e,f. The former shows the titration curve for $0.2 \mathrm{~g}$ of suspension in $0.03 \mathrm{M} \mathrm{NaNO}_{3}$, as well as the corresponding titration curve for the blank solution. The section point corresponds to the point of zero charge (pzc) of the biochar, equal to 7.4 according to the potentiometric mass titration technique. The point of zero charge of different biochars reported in the literature covers a wide $\mathrm{pH}$ range. Similar pzc values are reported when the minerals are limited, as in the case of biochars from spent coffee grounds [26], when they are removed from the surface, as in the case of treated biochars [48], or in cases where the minerals do not present acid-base behavior.

Across the whole $\mathrm{pH}$ range, the two curves have significant differences, indicating that a large quantity of surface sites can interact with the $\mathrm{H}^{+}$ions in the solution. These sites consume or release $\mathrm{H}^{+}$in the solution, depending on the $\mathrm{pH}$. Figure $2 \mathrm{f}$ shows the amount of $\mathrm{H}^{+}$consumed as a function of the solution $\mathrm{pH}$. There is a buffering effect in the $\mathrm{pH}$ region 9-11, while no surface sites are active for $\mathrm{pH}$ values between 7 and 8.5 . There are some active sites at lower $\mathrm{pH}$ values which can consume $\mathrm{H}^{+}$, though they are less in number. Therefore, the biochar's buffer activity in the acidic region is rather limited, although sites at $\mathrm{pH}<4$ cannot be excluded. The above findings can be seen in the differential curve for the $\mathrm{H}^{+}$consumed, shown in the inset of Figure $2 \mathrm{f}$.

\subsection{Oxidative Degradation of Antibiotics}

The beneficial influence of increasing the dosage of biochar on SMX removal is presented in Figure 3. This removal is due to the oxidation of SMX after the activation of SPS by the BC surface. Indeed, a sharp decrease in SMX concentration can be seen immediately after the SPS addition. At the same time, the differences in adsorption (i.e., before SPS addition) are not significant for the two dosages tested. The activation of SPS progressively decreases the solution $\mathrm{pH}$ from its initial value of 5.6 to about 3.5 at the end of the experiment; this may accelerate the removal of SMX, as shown in Figure 6. Assuming that SMX degradation follows pseudo-first-order kinetics, the apparent kinetic constants $\left(k_{a p p}\right)$ can be computed if the natural logarithm of the normalized concentration shown in Figure 3 is plotted against time. (More details on the kinetic analysis can be found in [47].)

The $k_{\text {app }}$ values were computed and were equal to $5.6 \times 10^{-3} \mathrm{~min}^{-1}$ at $100 \mathrm{mg} \mathrm{L}^{-1}$ biochar and $1.0 \times 10^{-2} \mathrm{~min}^{-1}$ at $500 \mathrm{mg} \mathrm{L}^{-1}$ biochar, i.e., a five-fold increase in biochar concentration resulted in only a two-fold increase in the rate constant. For RHB850 the $k_{\text {app }}$ values were computed and were equal to $2.4 \times 10^{-2} \mathrm{~min}^{-1}$ at $100 \mathrm{mg} \mathrm{L}^{-1}$ biochar and $1.4 \times 10^{-1} \mathrm{~min}^{-1}$ at $500 \mathrm{mg} \mathrm{L}^{-1}$ biochar [40]. These $k_{a p p}$ values were significantly higher than the corresponding values for RHB700, and the influence of biochar mass was also higher, since the $k_{a p p}$ value increased almost six times compared with two times for the 
RHB700. This is the first, although weak, evidence that the carbonaceous phase acts in a different way in the degradation process for RHB700 compared to RHB850.

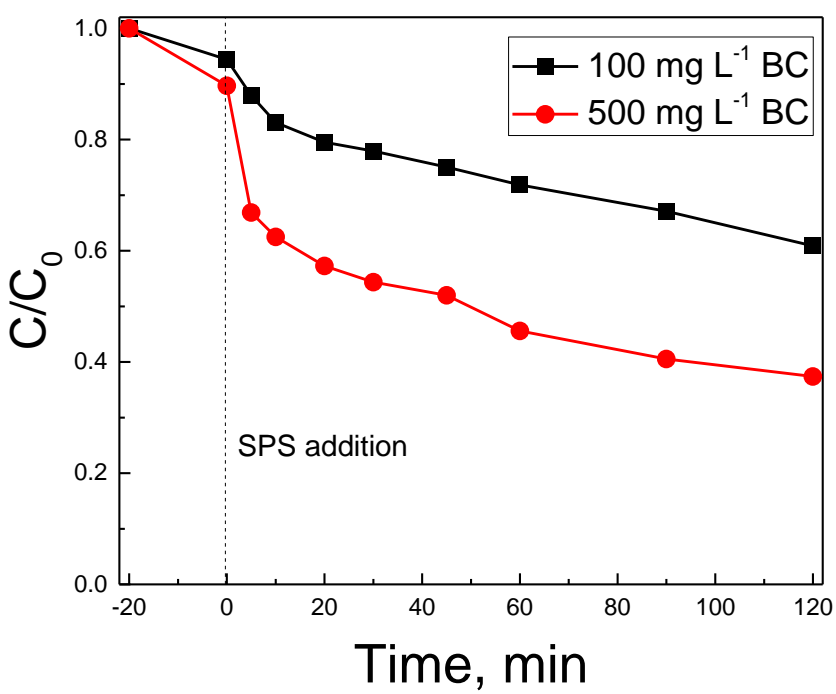

Figure 3. Effect of RHB700 dosage on $500 \mu \mathrm{g} \mathrm{L}^{-1}$ SMX degradation with $500 \mathrm{mg} \mathrm{L}^{-1}$ SPS in UPW and inherent $\mathrm{pH}$.

The influence of increasing SPS concentration is presented in Figure 4. In the absence of SPS, the removal of SMX is attributed solely to adsorption, which is moderate at about $12 \%$ after $120 \mathrm{~min}$. The addition of SPS increases degradation with values at $120 \mathrm{~min}$ of 39, 55 and $63 \%$ at 500,1000 and $1500 \mathrm{mg} \mathrm{L}^{-1}$ SPS concentration, respectively. Interestingly, the use of $1500 \mathrm{mg} \mathrm{L}^{-1}$ SPS alongside $100 \mathrm{mg} \mathrm{L}^{-1} \mathrm{BC}$ results in almost the same performance as the combination of $500 \mathrm{mg} \mathrm{L}^{-1}$ SPS with $500 \mathrm{mg} \mathrm{L}^{-1} \mathrm{BC}$ (Figure 3). From an environmental perspective, using a higher amount of BC is preferable to using higher amounts of SPS, since the latter increases the sulfate concentration in water.

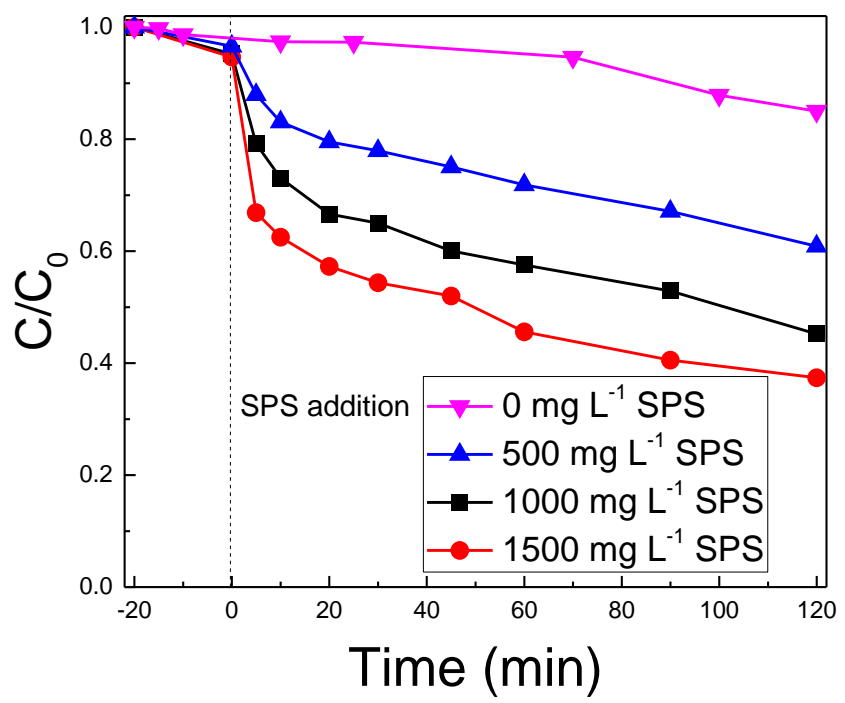

Figure 4. Effect of SPS concentration on $500 \mu \mathrm{g} \mathrm{L}^{-1} \mathrm{SMX}$ degradation with $100 \mathrm{mg} \mathrm{L}^{-1} \mathrm{RHB700}$ in UPW and inherent $\mathrm{pH}$.

Figure 5 shows the effect of the initial SMX concentration on its degradation, which substantially decreases with increasing concentration from 500 to $1000 \mu \mathrm{g} \mathrm{L}^{-1}$ but remains fairly constant between 1000 and $2000 \mu \mathrm{g} \mathrm{L}^{-1}$. This is also reflected in the $k_{a p p}$ values, which drop by an order of magnitude from $10^{-2} \mathrm{~min}^{-1}$ at $500 \mu \mathrm{g} \mathrm{L}^{-1}$ to $3.4 \pm 0.8 \times 10^{-3} \mathrm{~min}^{-1}$ 
at $1000-2000 \mu \mathrm{g} \mathrm{L}^{-1}$. The fact that the rate constant depends on the initial concentration implies that the reaction is not a true first-order reaction for the range of concentrations tested.

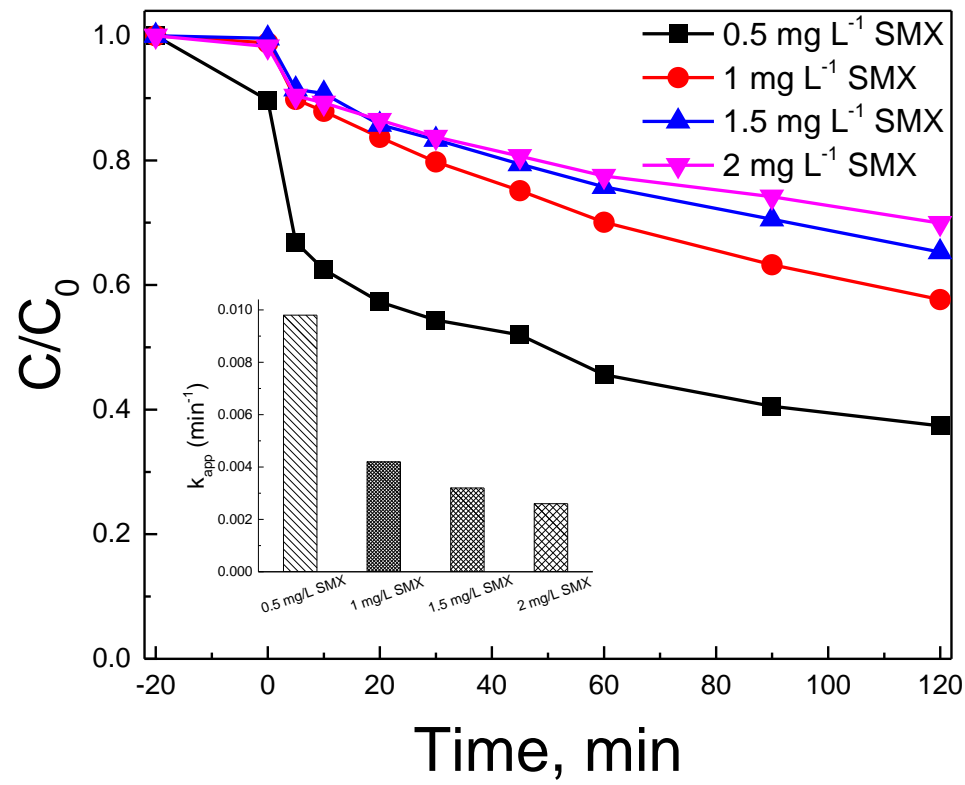

Figure 5. Effect of initial SMX concentration on its degradation with $500 \mathrm{mgL}^{-1} \mathrm{RHB700}$ and $500 \mathrm{mgL}^{-1}$ SPS in UPW and inherent $\mathrm{pH}$. Inset graph shows the corresponding $\mathrm{k}_{\mathrm{app}}$ values.

The influence of the initial solution $\mathrm{pH}$ on the SMX adsorption and degradation was also studied, and the results are presented in Figure 6. As can be seen in Figure 6a, adsorption is significantly affected by $\mathrm{pH}$, and favored under acidic conditions. In contrast, inherent and alkaline conditions do not seem to favor electrostatic adsorption; this is consistent with the isoelectric point of SMX and, generally, with its acid-base behavior. SMX is positively charged under highly acidic conditions $(\mathrm{pH}<1.4)$ and negatively charged at $\mathrm{pH}>6[27,28]$. RHB700 has a point of zero charge equal to 7.4 , which means that the surface groups do not have significant acidic or alkaline properties. Under alkaline conditions, both SMX and the biochar surface are negatively charged; thus, adsorption is not favored. The small amount of adsorbed SMX can be attributed to $\pi-\pi$ interactions. At inherent $\mathrm{pH}, \mathrm{SMX}$ is almost neutral, and the surface has only a small positive charge. The $\pi-\pi$ interactions could still play a significant role [49] in the adsorption although the interaction between the neutral SMX and the slightly positive surface cannot be excluded. In the acidic region, the higher positive charge of the surface is beneficial for the adsorption of the neutral form of SMX, in accordance with previously reported results [26,47].

The addition of $500 \mathrm{mg} \mathrm{L}^{-1}$ SPS changes the process, since the activation of SPS and the oxidation of SMX lower the solution $\mathrm{pH}$ due to the production of $\mathrm{HSO}_{4}{ }^{-}$, a side effect of sulfate radical formation. This activation is rapid during the first $10 \mathrm{~min}$, as can be seen from Figure 6b. For the inherent $\mathrm{pH}$ especially, this sharp decrease is more pronounced since the $\mathrm{pH}$ can be shifted to lower values easily compared to the experiments in highly basic and/or acidic environments. The above findings are similar to those of previous studies for the antibiotic SMX [40,47].

The $\mathrm{pH}$ effect is a complex issue related to many factors, including the type of organic substrate under consideration. This is demonstrated in Figure 7, which shows ampicillin degradation at two different solution $\mathrm{pH}$ values. AMP has both basic and acidic groups; it is protonated at $\mathrm{pH}<2.6$, while it is negatively charged at $\mathrm{pH}>7.4$ [50]. Therefore, the extent of AMP adsorption onto the biochar surface is not significant at $\mathrm{pH}=3.1$, due to the electrostatic repulsions between the positive ions of AMP and the positive surface sites, unlike the case of SMX. This reduces the extent of AMP degradation since it is difficult for the molecule to interact with the biochar surface. In contrast, degradation is higher at the 
inherent $\mathrm{pH}$ of 5.8, and this is more pronounced during the early stages of the reaction. Interestingly, the two curves nearly overlap after $45 \mathrm{~min}$, when the $\mathrm{pH}$ values of the two suspensions approach a similar value, close to 3 .
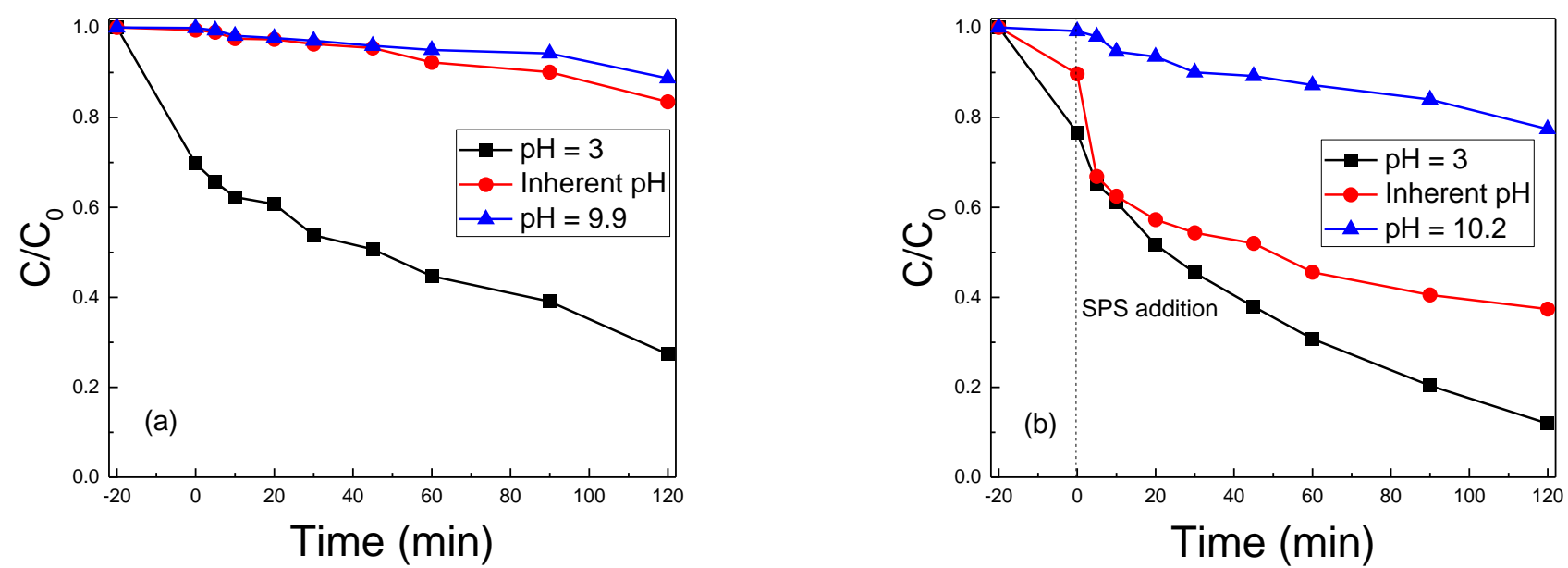

Figure 6. Effect of initial solution $\mathrm{pH}$ on the adsorption (a) and degradation (b) of $500 \mu \mathrm{g} \mathrm{L}^{-1}$ SMX adsorption with $500 \mathrm{mg} \mathrm{L}^{-1} \mathrm{RHB700}$ in UPW.

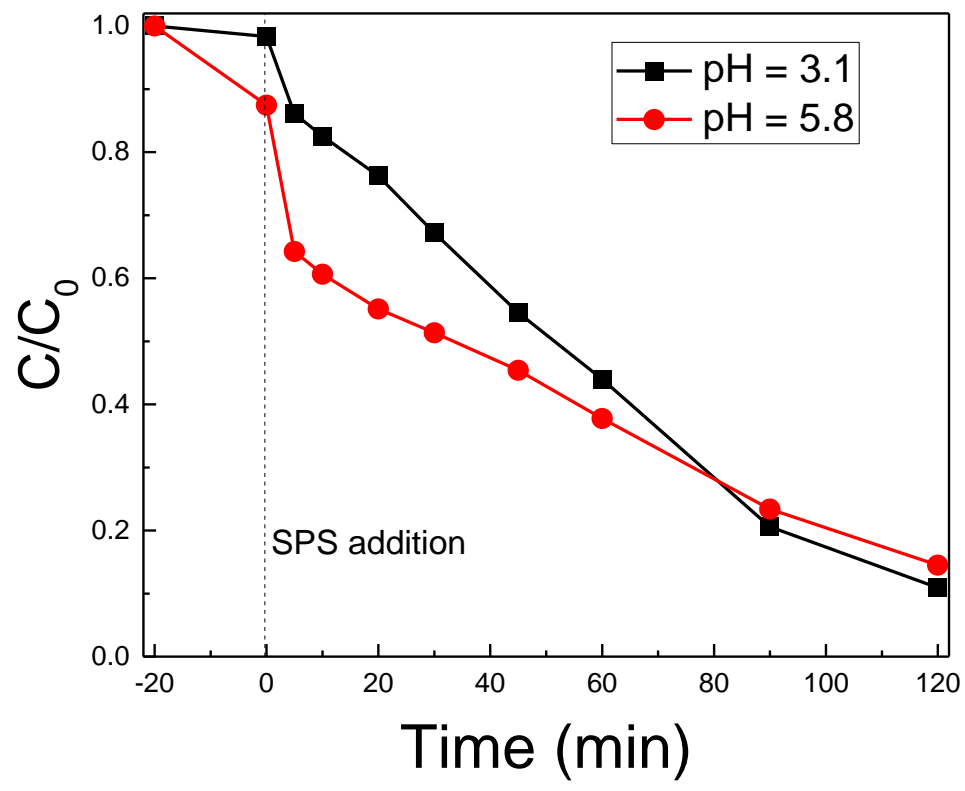

Figure 7. Effect of initial $\mathrm{pH}$ on $500 \mu \mathrm{g} \mathrm{L}{ }^{-1}$ AMP degradation with $500 \mathrm{mg} \mathrm{L}^{-1}$ RHB700 and $500 \mathrm{mg} \mathrm{L}^{-1}$ SPS in UPW.

\subsection{The Water Matrix Effect}

The influence of the water matrix was investigated via experiments in bottled water and secondary treated wastewater, and the results are shown in Figure 8. SMX degradation decreases with increasing matrix complexity, i.e., the conversion at 120 min drops from $61 \%$ in UPW to $17 \%$ in WW. This is due to the inherent presence of various inorganic and organic non-target species and their competition with SMX for the oxidizing species and the catalyst surface sites. The negative effect of inorganic species in BW is less pronounced, and this implies that the residual effluent organic matter in WW may be primarily responsible for the reduced performance. 


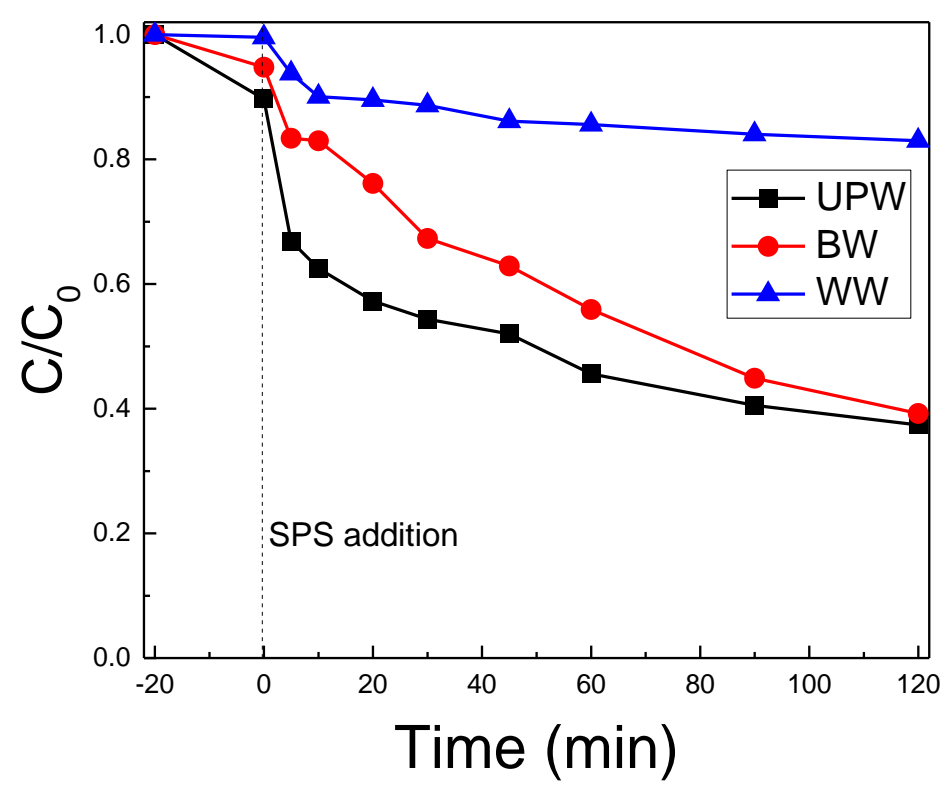

Figure 8. Effect of water matrix on $500 \mathrm{mg} \mathrm{L}^{-1} \mathrm{SMX}$ degradation with $500 \mathrm{mg} \mathrm{L}^{-1} \mathrm{RHB700}$ and $500 \mathrm{mg} \mathrm{L}^{-1}$ SPS and inherent $\mathrm{pH}$.

In further experiments, UPW was spiked with either $250 \mathrm{mg} \mathrm{L}^{-1}$ bicarbonate or $10 \mathrm{mg} \mathrm{L}^{-1}$ humic acid to evaluate their effect on SMX degradation. Bicarbonate is the dominant ion in natural waters, and the chosen concentration matches that in BW. Humic acid is representative of natural organic matter, and the chosen concentration corresponds to the organic content typically found in WW. The results are summarized in Figure 9: the presence of either species retards SMX degradation and this is more pronounced for bicarbonate, i.e., the conversion at $120 \mathrm{~min}$ in UPW is nearly halved when bicarbonate is added to the solution. The inset of Figure 9 shows the effect of bicarbonate on SMX adsorption onto the biochar surface. Interestingly, adsorption is not affected to a great extent during the equilibration period of the experiment (i.e., $20 \mathrm{~min}$ ) and is only partially impeded at prolonged contact times, which may, to some extent, explain the reduced SMX degradation. This can be partially explained by the differences in the starting solution $\mathrm{pH}$, which is shifted to higher values in the case of bicarbonates. However, the unwanted competitive interactions between SMX and the non-target species for the oxidizing species seem to be the dominant factor in the performance shown in Figure 9.

\subsection{The Role of Radical Scavengers and Oxidant}

The addition of methanol or t-butanol $\left(0.12 \mathrm{~mol} \mathrm{~L}^{-1}\right)$, which are well-known radical scavengers, was investigated to check the contribution of free radicals to the degradation process. Methanol reacts with both sulfate and hydroxyl radicals at similar rates, while t-butanol reacts preferentially with hydroxyl radicals [37,51]. Moreover, the addition of sodium azide ( $\left.1.54 \mathrm{mmol} \mathrm{L}^{-1}\right)$, a well-known scavenger of singlet oxygen, was also investigated [11]. Table 1 shows the $k_{a p p}$ values for SMX degradation with RHB700, as well as the amount of SMX adsorbed at $20 \mathrm{~min}$; moreover, the respective data for RHB850 are also given [40]. SMX degradation with RHB700 is impeded substantially by t-butanol, while methanol only slightly decreases oxidation; this may indicate that the first step is the formation of sulfate radicals followed by their partial conversion to hydroxyl radicals. The scavenger action of $\mathrm{t}-\mathrm{BuOH}$ may imply that hydroxyl radicals dominate over sulfate radicals. In addition, the lower adsorption in the presence of $\mathrm{t}-\mathrm{BuOH}$ suggests that the oxidation can occur at the interface with biochar where adsorption becomes important; this is in accordance with the hindered adsorption of SMX in the presence of $\mathrm{t}-\mathrm{BuOH}$, in contrast with the $\mathrm{MeOH}$ case. 


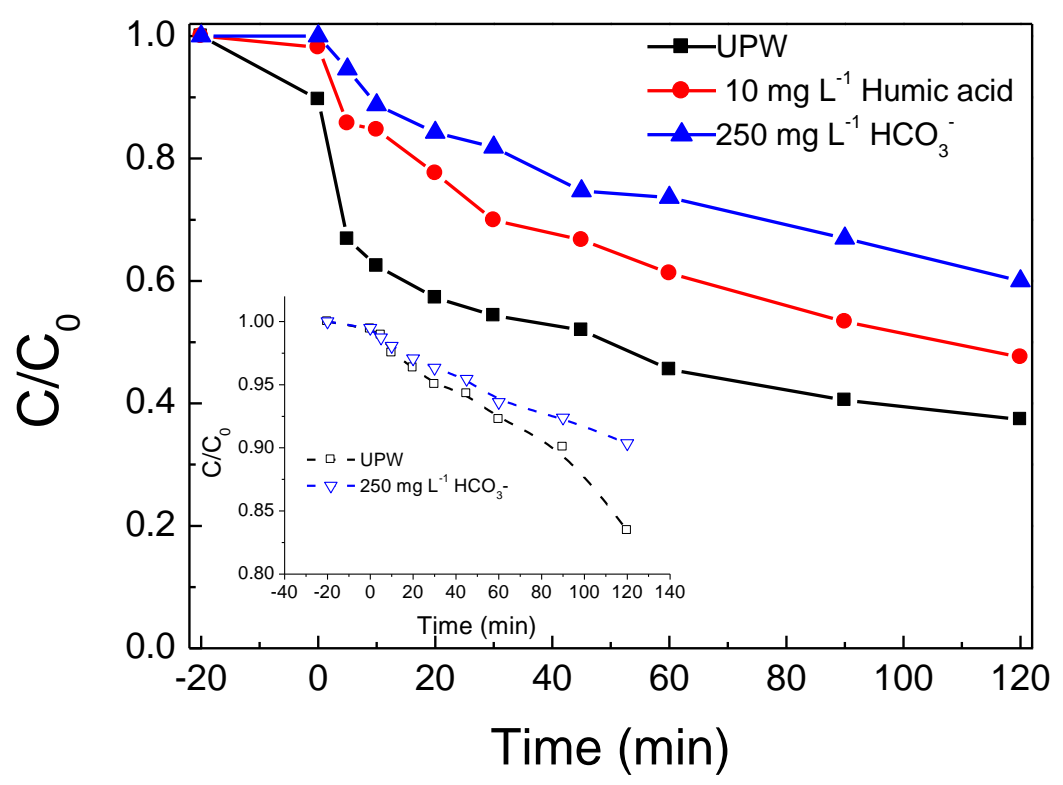

Figure 9. Effect of the addition of bicarbonate or humic acid on $500 \mu \mathrm{g} \mathrm{L}{ }^{-1}$ SMX degradation with $500 \mathrm{mg} \mathrm{L}^{-1}$ RHB700 and $500 \mathrm{mg}$ L SPS at inherent $\mathrm{pH}$. Inset graph shows adsorption of SMX in the presence and absence of bicarbonate.

Table 1. The $k_{a p p}$ values for SMX degradation and the amount of SMX adsorbed at $20 \mathrm{~min}$ in $\mu \mathrm{g}$ of $\mathrm{SMX} / \mathrm{mg}$ biochar for RHB700 and RHB850 in the presence of different scavengers. The values for UPW are also presented.

\begin{tabular}{ccccc}
\hline & \multicolumn{2}{c}{ RHB700 } & \multicolumn{2}{c}{ RHB850 } \\
Scavenger & $k_{\text {app }}\left(\mathbf{m i n}^{-\mathbf{1})}\right.$ & $\begin{array}{c}\mu \mathrm{g} \mathrm{SMX/mg} \\
\text { Biochar }\end{array}$ & $\boldsymbol{k}_{\text {app }}\left(\mathbf{m i n}^{-\mathbf{1})}\right.$ & $\begin{array}{c}\boldsymbol{\mu} \text { SMX/mg } \\
\text { Biochar }\end{array}$ \\
\hline $\mathrm{UPW}$ & $1.0 \times 10^{-2}$ & 0.103 & $2.4 \times 10^{-2}$ & 1.45 \\
$\mathrm{MeOH}$ & $7.1 \times 10^{-3}$ & 0.022 & $1.6 \times 10^{-2}$ & 1.14 \\
$\mathrm{t}-\mathrm{BuOH}$ & $3.5 \times 10^{-3}$ & 0.0099 & $1.5 \times 10^{-2}$ & 0.56 \\
$\mathrm{NaN}_{3}$ & $5.2 \times 10^{-3}$ & 0.036 & $8.6 \times 10^{-3}$ & 1.23 \\
\hline
\end{tabular}

In the case of RH850, the radical pathway seems to be less important since the addition of either alcohol has a moderate effect; nonetheless, the reaction is impeded substantially in the presence of sodium azide, unlike for RHB700. The different contribution levels between radical and non-radical pathways for the two biochars can be explained as follows: (i) the higher pyrolysis temperature employed for RHB850 extended the carbonization process, thus resulting in a more active carbon phase than RHB700 (this is evidenced by the XRD and TGA results [40]); (ii) the adsorption of SMX on RHB850 is greater than on RH700, which implies that electron transfer and the non-radical pathways occur more easily. The above explanations are in accordance with previous studies suggesting that SMX degradation may occur not only through sulfate and hydroxy radicals but also through singlet oxygen ${ }^{1} \mathrm{O}_{2}$ and electron transfer routes [35,52].

Figure 10 shows a comparison between different oxidizing agents, i.e., $2.1 \mathrm{mM}$ sodium persulfate (this corresponds to $500 \mathrm{mg} \mathrm{L}^{-1}$ ), $2.1 \mathrm{mM}$ hydrogen peroxide and $1.4 \mathrm{mM}$ sodium percarbonate. The concentration of the latter is $65 \%$ of the concentration of hydrogen peroxide since it contains 1.5 hydrogen peroxide molecules. Evidently, RHB700 cannot activate either $\mathrm{H}_{2} \mathrm{O}_{2}$ or percarbonate efficiently, unlike SPS, whose activation leads to the generation of sulfate radicals and hydroxyl radicals, as well as initiating non-radical pathways. 


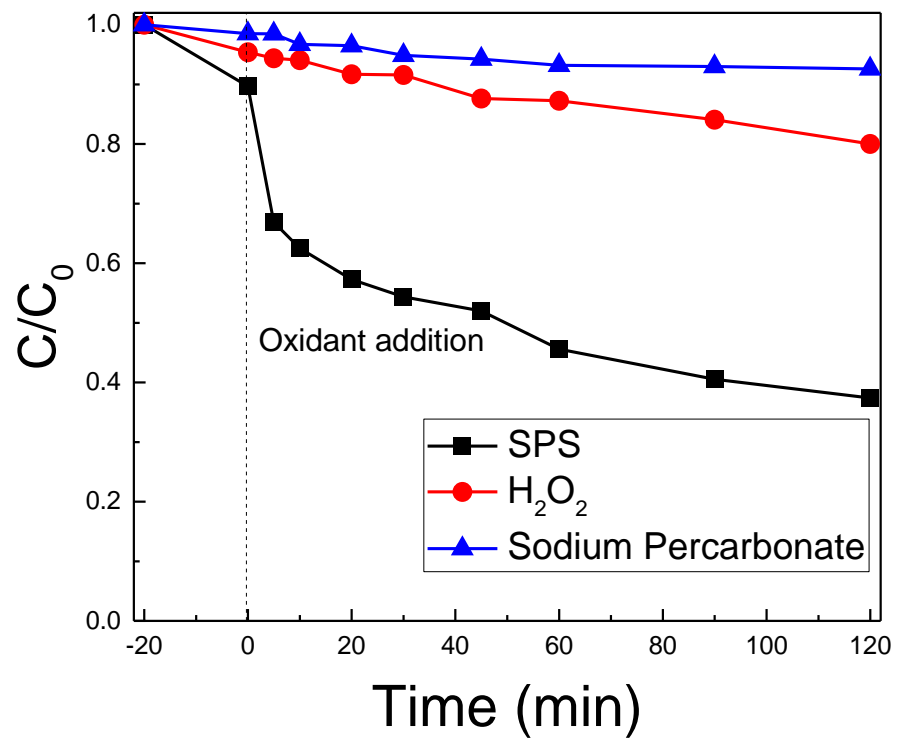

Figure 10. Effect of different oxidizing agents on $500 \mu \mathrm{g} \mathrm{L}-1$ SMX degradation with $500 \mathrm{mg} \mathrm{L}^{-1}$ RHB700 in UPW and inherent $\mathrm{pH}$.

\subsection{The Effect of the Antibiotic Type}

In a final set of experiments, a comparison was made between the different biochars (RHB700 and RHB850) and the various antibiotics (SMX, AMP and NOR). The results are presented in Figure 11.

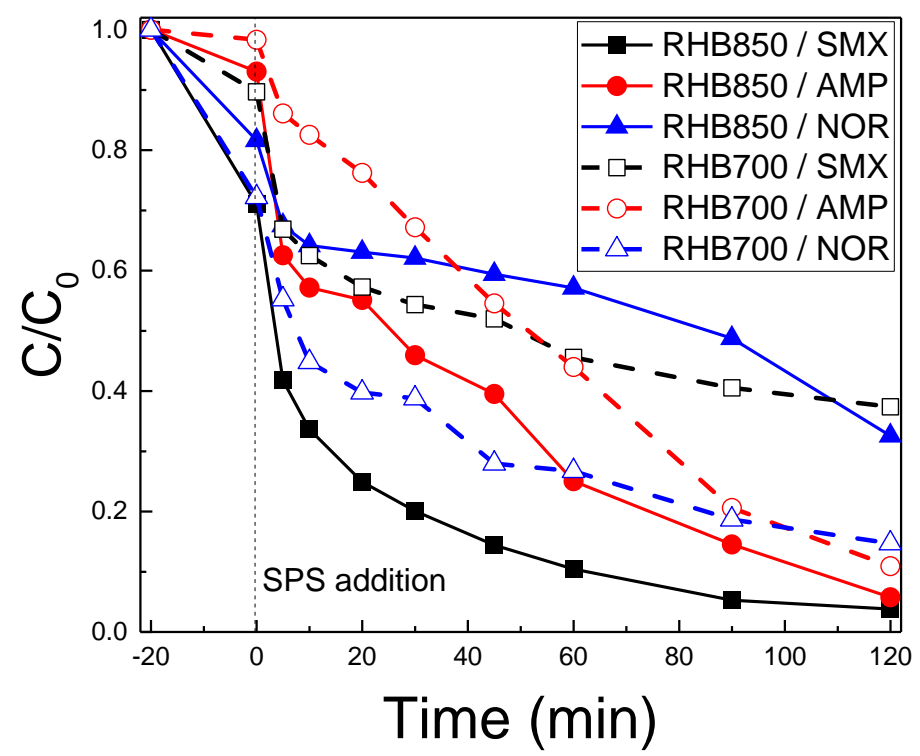

Figure 11. Degradation of various $500 \mathrm{mg} \mathrm{L}^{-1}$ antibiotics with $100 \mathrm{mg} \mathrm{L}^{-1} \mathrm{RHB} 850$ or $500 \mathrm{mgL}^{-1}$ RHB700 and $500 \mathrm{mg} \mathrm{L}^{-1}$ SPS in UPW and inherent $\mathrm{pH}$.

The three antibiotics under consideration exhibited different recalcitrance to oxidative degradation, depending on the type of biochar used. In the case of RHB850, the relative activity decreased in the order $\mathrm{SMX}>\mathrm{AMP}>\mathrm{NOR}$, and this changed to NOR $>\mathrm{AMP}>\mathrm{SMX}$ for RHB700. This occurred because each compound interacts differently with the biochar surface; such interactions are defined by the $\mathrm{pH}$ of the suspension, which determines the charge of the species in the solution and the surface groups. Generally, high $\mathrm{pH}$ values are not beneficial for the oxidation process since the negative charge of the surface and the negative charges of the compounds are incompatible. The most favorable combination 
is the neutral or slightly positive form of the antibiotics with low positive surface charge. This requires a $\mathrm{pH}$ of around 3 to 4 for SMX and $\mathrm{pH}$ of 4 or higher for AMP, while NOR requires an even higher $\mathrm{pH}$ since it is found in neutral form at $6<\mathrm{pH}<8.5$ [53]. NOR was found to interact more strongly with an organic solvent than with an aqueous solvent in the case of both cationic and zwitterionic/neutral forms [54]. This agrees well with the activity order for RHB850. In contrast, SMX and NOR exhibited the opposite behavior with RHB700, probably due to the differences in the carbonaceous phase. In the case of RHB700 with an almost neutral surface, the surface sites are fewer and there are some sites with a pK close to 6.5, as shown in Figure 2f. These sites can be considered responsible for the high adsorption of NOR and consequently the high removal rate compared to SMX. Regarding AMP degradation, it can be considered that the activation of SPS influences the form of AMP in the solution. AMP has a carboxy and an amino group with zwitterionic behavior. The two groups develop a different charge and interact between themselves, forming larger clusters. The $\mathrm{pH}$ influences these interactions and, during SPS activation, the produced $\mathrm{H}^{+}$ions neutralize part of the $-\mathrm{COO}^{-}$charge. This may change not only the speciation of the AMP but also the solution $\mathrm{pH}$. It was found that the adsorption of AMP on activated carbon was favored at $\mathrm{pH}=4$ [55]. This $\mathrm{pH}$ can be reached after a certain reaction time, indicating that the whole process is under kinetic control.

\section{Materials and Methods}

\subsection{Chemicals and Water Matrices}

Sulfamethoxazole (SMX, $\mathrm{C}_{10} \mathrm{H}_{11} \mathrm{~N}_{3} \mathrm{O}_{3} \mathrm{~S}, 99+\%$, CAS number: 723-46-6) and norfloxacin (NOR, $\mathrm{C}_{16} \mathrm{H}_{18} \mathrm{FN}_{3} \mathrm{O}_{3}, 98+\%$, CAS number: 70458-96-7) were obtained from Sigma-Aldrich (St. Louis, MO, USA.) Ampicillin trihydrate (AMP, $\mathrm{C}_{16} \mathrm{H}_{19} \mathrm{~N}_{3} \mathrm{O}_{4} \mathrm{~S}-3 \mathrm{H}_{2} \mathrm{O}, 99 \%$, CAS number: 69-53-4) was purchased from SERVA (Heidelberg, Germany). Sodium persulfate (SPS, $\mathrm{Na}_{2} \mathrm{~S}_{2} \mathrm{O}_{8} 99 \%$, CAS number: 7775-27-1) was purchased from Scharlau (Barcelona, Spain).

Most of the experiments were carried out in ultrapure water (UPW). Other matrices included (i) commercially available bottled water (BW: $\mathrm{pH}=7.7,355 \mu \mathrm{Scm}^{-1}$ conductivity containing (in $\mathrm{mg} \mathrm{L}^{-1}$ ): 237 bicarbonate; 3.7 chloride $(\mathrm{Cl}) ; 7.8$ sulfate $(\mathrm{S}) ; 1.1$ nitrate $(\mathrm{N}) ; 75.5$ calcium $(\mathrm{Ca}) ; 5.1$ magnesium $(\mathrm{Mg}) ; 2.1$ sodium $(\mathrm{Na}) ; 0.65$ potassium $(\mathrm{K})$ ions), (ii) secondary treated wastewater (WW) taken from the University of Patras campus (WWTP) $\left(\mathrm{pH}=8\right.$, conductivity $=1.682 \mathrm{mS} \mathrm{cm}^{-1}$, total organic $\mathrm{C}=2.46 \mathrm{mg} \mathrm{L}^{-1}$, chemical oxygen demand $=48.53 \mathrm{mg} \mathrm{L}^{-1}$, total suspended solids $=22 \mathrm{mg} \mathrm{L}^{-1},[\mathrm{Cl}]=262.41 \mathrm{mg} \mathrm{L}^{-1}$, $\left[\mathrm{PO}_{4}^{3-}\right]=14.98 \mathrm{mg} \mathrm{L}^{-1},\left[\mathrm{HCO}_{3}^{-}\right]=278 \mathrm{mg} \mathrm{L}^{-1},\left[\mathrm{Br}^{-}\right]=165,64 \mathrm{mg} \mathrm{L}^{-1},\left[\mathrm{Ca}^{2+}\right]=$ $112 \mathrm{mg} \mathrm{L}^{-1}$ ) and (iii) ultrapure water (UPW: $\mathrm{pH}=6.5$ ) spiked with various water constituents such as humic acid (CAS no. 1415-93-6), bicarbonate (CAS no. 144-55-8), chloride (CAS no. 7647-14-5), sodium azide (CAS no. 26628-22-8), t-butanol (CAS no. 7565-0) and methanol (CAS no. 67-56-1). All these were purchased from Sigma-Aldrich (St. Louis, MO, USA).

\subsection{Preparation and Characterization of Biochar}

The BC was prepared from rice husk supplied by Agrino (Agrino, Greece), a local company producing rice in Western Greece. The biomass was dried overnight at $50{ }^{\circ} \mathrm{C}$ and sieved to 1.18 to $0.15 \mathrm{~mm}$. Then, a pre-weighed sample was placed into a custom-made quartz vessel and heated to $700{ }^{\circ} \mathrm{C}$ under a static atmosphere with a limited amount of air (i.e., $\approx 20 \mathrm{~mL}$ per $200 \mathrm{~g}$ of starting biomass) in a gradient temperature furnace (LH 60/12, Nabertherm GmbH, Lilienthal, Germany).

The prepared BC was characterized using several techniques as follows. $\mathrm{N}_{2}$ adsorption isotherms at liquid $\mathrm{N}_{2}$ temperature (Tristar 3000 porosimeter, Micromeritics) were used for the determination of specific surface area, micropore surface area and pore size distribution. X-ray diffraction (XRD) patterns were recorded using a Bruker D8 Advance diffractometer (Billerica, MA, USA) equipped with a nickel-filtered CuKa (1.5418 $)$ ) radiation source. A scanning electron microscope (SEM, JEOL JSM6300, JEOL GmbH, Freising, Germany,) equipped with EDS was used for the determination of morphology. The Fourier transform 
infrared (FTIR) spectrum was recorded at $4000-400 \mathrm{~cm}^{-1}$ using a Perkin Elmer Spectrum RX FTIR system (Waltham, MA, USA) with a $\mathrm{KBr}$ pellet with $1 \% \mathrm{w} / \mathrm{w} \mathrm{BC}$. The thermogravimetric analysis of the BC was performed in a TGA Perkin Elmer system (Waltham, MA, USA) at a heating rate of $20^{\circ} \mathrm{C} \mathrm{min}^{-1}$ under an air atmosphere with a flow of $20 \mathrm{~mL} \mathrm{~min}^{-1}$. The potentiometric titration method was used to determine the point of zero charge and the acid-base behavior of the BC [56].

\subsection{Experimental Procedures}

A stock solution of SMX $\left(50 \mathrm{mg} \mathrm{L}^{-1}\right)$ in UPW was prepared and used for all the experiments. In a typical run, $120 \mathrm{~mL}$ of an aqueous solution (BW in most cases) containing $500 \mu \mathrm{g} \mathrm{L}^{-1} \mathrm{SMX}$ (some experiments were performed at different concentrations) was loaded into an open glass cylindrical reaction vessel under continuous stirring at ambient temperature. The BC mass was added into the reactor under stirring, and after $20 \mathrm{~min}$ SPS was added to start the reaction under magnetic stirring. Samples of $1.2 \mathrm{~mL}$ were periodically drawn from the reactor, an excess of methanol was added $\left(5 \mathrm{~mol} \mathrm{~L}^{-1}\right)$ to quench the reaction and the samples were filtered with a $0.2 \mu \mathrm{m}$ (PVDF, Whatman, Maidstone, UK) syringe filter to remove $\mathrm{BC}$ particles and then analyzed using high-performance liquid chromatography (HPLC) (Waters Alliance 2695(Waters 2996 Milford, PA, USA). The Kinetex XB-C18 100A (2.6 $\mu \mathrm{m}$ inner diameter (i.d.), $2.1 \mathrm{~mm} \times 50 \mathrm{~mm}$ ) column and a $0.5 \mu \mathrm{m}$ inline filter (KrudKatcher Ultra) were both purchased from Phenomenex (Phenomenex, Madrid Avenue, Torrance, CA, USA). The isocratic mobile phase consisted of UPW (68\%) and acetonitrile (32\%). The AMP absorbance peaked at $210 \mathrm{~nm}$, the SMX absorbance peaked at $270 \mathrm{~nm}$ and the NOR absorbance peaked at $278 \mathrm{~nm}$, as determined from the corresponding UV-vis absorption spectra. The mobile phase used for SMX detection was $0.1 \%$ phosphoric acid/acetonitrile $(85 \% / 10 \%)$ [40]. The same ratio was used for NOR, while $90 \% / 10 \%$ was used for AMP. More details can be found in [57].

\section{Conclusions}

The present study indicates that differently prepared biochars may have different properties and that this can affect both the adsorption and the oxidative decomposition of contaminants. Therefore, the choice of an appropriate catalytic material cannot be unambiguous, and several factors must be considered, including the operating parameters and the specific environmental problem to be tackled. The main conclusions of the present study are summarized as follows:

(i) Biochar produced from rice husk is effective for the persulfate-driven oxidation of various antibiotics such as SMX, NOR and AMP.

(ii) Treatment performance depends on both the type and the properties of the biochar and the contaminant under consideration.

(iii) Degradation seems to be surface-sensitive, and radical and non-radical pathways may occur. Higher pyrolysis temperatures favor a non-radical pathway, while lower temperatures favor a radical pathway.

(iv) Degradation in real matrices occurs more slowly than in pure water, as bicarbonate ions have a detrimental effect on the degradation.

(v) Adsorption of SMX plays an important role in the degradation process. At the same time, the oxidation in the bulk solution is limited.

(vi) The preparation parameters can influence the catalytic performance.

Author Contributions: E.A.: investigation, formal analysis and writing; Z.F.: investigation and reviewing; J.V.: investigation and writing — reviewing and editing; I.D.M.: resources and investigation; D.M.: conceptualization, funding acquisition and editing. All authors have read and agreed to the published version of the manuscript.

Funding: E.A., J.V. and D.M. acknowledge support of this work by the project "Biochars from Valorized Biomass, Oxidants, Hazardous and Emerging Micro-Pollutants and the Water Matrix: Does their Interplay Affect Notably Treatment Performance?" funded by the Hellenic Foundation 
for Research and Innovation (H.F.R.I.) under the "First Call for H.F.R.I. Research Projects to support Faculty members and Researchers and the Procurement of High-Cost Research Equipment" grant (Project Number: 81080).

Acknowledgments: The authors are grateful to K. Govatsi, University of Patras, Laboratory of Electron Microscopy and Microanalysis (LEMM) for the SEM measurements and to Agrino S.A. for the provision of rice husk.

Conflicts of Interest: The authors declare no conflict of interest.

\section{References}

1. Tongcumpou, C.; Usapein, P.; Tuntiwiwattanapun, N. Complete Utilization of Wet Spent Coffee Grounds Waste as a Novel Feedstock for Antioxidant, Biodiesel, and Bio-Char Production. Ind. Crop. Prod. 2019, 138, 111484. [CrossRef]

2. Goodman, B.A. Utilization of Waste Straw and Husks from Rice Production: A Review. J. Bioresour. Bioprod. 2020, 5, 143-162. [CrossRef]

3. Manariotis, I.D.; Fotopoulou, K.N.; Karapanagioti, H.K. Preparation and Characterization of Biochar Sorbents Produced from Malt Spent Rootlets. Ind. Eng. Chem. Res. 2015, 54, 9577-9584. [CrossRef]

4. Zeng, H.; Qi, W.; Zhai, L.; Wang, F.; Zhang, J.; Li, D. Preparation and Characterization of Sludge-Based Magnetic Biochar by Pyrolysis for Methylene Blue Removal. Nanomaterials 2021, 11, 2473. [CrossRef] [PubMed]

5. El-Azazy, M.; Nabil, I.; Hassan, S.S.; El-Shafie, A.S. Adsorption Characteristics of Pristine and Magnetic Olive Stones Biochar with Respect to Clofazimine. Nanomaterials 2021, 11, 963. [CrossRef] [PubMed]

6. Vakros, J.; Manariotis, I.D.; Dracopoulos, V.; Mantzavinos, D.; Lianos, P. Biochar from Spent Malt Rootlets and Its Application to an Energy Conversion and Storage Device. Chemosensors 2021, 9, 57. [CrossRef]

7. Deng, J.; Li, J.; Song, S.; Zhou, Y.; Li, L. Electrolyte-Dependent Supercapacitor Performance on Nitrogen-Doped Porous Bio-Carbon from Gelatin. Nanomaterials 2020, 10, 353. [CrossRef] [PubMed]

8. Tsavatopoulou, V.D.; Vakros, J.; Manariotis, I.D. Lipid Conversion of Scenedesmus Rubescens Biomass into Biodiesel Using Biochar Catalysts from Malt Spent Rootlets. J. Chem. Technol. Biotechnol. 2020, 95, 2421-2429. [CrossRef]

9. Shi, C.; Li, Y.; Feng, H.; Jia, S.; Xue, R.; Li, G.; Wang, G. Removal of P-Nitrophenol Using Persulfate Activated by Biochars Prepared from Different Biomass Materials. Chem. Res. Chin. Univ. 2018, 34, 39-43. [CrossRef]

10. Varela Milla, O.; Rivera, E.B.; Huang, W.-J.; Chien, C.-C.; Wang, Y.-M. Agronomic Properties and Characterization of Rice Husk and Wood Biochars and Their Effect on the Growth of Water Spinach in a Field Test. J. Soil Sci. Plant Nutr. 2013, 13, 251-266. [CrossRef]

11. Grilla, E.; Vakros, J.; Konstantinou, I.; Manariotis, I.D.; Mantzavinos, D. Activation of Persulfate by Biochar from Spent Malt Rootlets for the Degradation of Trimethoprim in the Presence of Inorganic Ions. J. Chem. Technol. Biotechnol. 2020, 95, 2348-2358. [CrossRef]

12. Han, R.; Fang, Y.; Sun, P.; Xie, K.; Zhai, Z.; Liu, H.; Liu, H. N-Doped Biochar as a New Metal-Free Activator of Peroxymonosulfate for Singlet Oxygen-Dominated Catalytic Degradation of Acid Orange 7. Nanomaterials 2021, 11, 2288. [CrossRef]

13. Wang, C.; Huang, R.; Ruirui Sun, R.; Yang, J.; Sillanpää, M. A review on persulfates activation by functional biochar for organic contaminants removal: Synthesis, characterizations, radical determination, and mechanism. J. Environ. Chem. Eng. 2021, 9, 106267. [CrossRef]

14. Zhang, H.; Xu, F.; Wu, Y.; Hu, H.; Dai, X. Progress of Potato Staple Food Research and Industry Development in China. J. Integr. Agric. 2017, 16, 2924-2932. [CrossRef]

15. Aulakh, D.S.; Singh, J.; Kumar, S. The Effect of Utilizing Rice Husk Ash on Some Properties of Concrete-A Review. Curr. World Environ. 2018, 13, 224-231. [CrossRef]

16. Kraehmer, H.; Thomas, C.; Vidotto, F. Rice Production in Europe. In Rice Production Worldwide; Chauhan, B.S., Jabran, K., Mahajan, G., Eds.; Springer International Publishing: Cham, Switzerland, 2017; pp. 93-116, ISBN 978-3-319-47514-1.

17. Mirmohamadsadeghi, S.; Karimi, K. Recovery of silica from rice straw and husk. In Current Developments in Biotechnology and Bioengineering; Elsevier: Amsterdam, The Netherlands, 2020; pp. 411-433, ISBN 978-0-444-64321-6.

18. Meng, H.; Nie, C.; Li, W.; Duan, X.; Lai, B.; Ao, Z.; Wang, S.; An, T. Insight into the Effect of Lignocellulosic Biomass Source on the Performance of Biochar as Persulfate Activator for Aqueous Organic Pollutants Remediation: Epicarp and Mesocarp of Citrus Peels as Examples. J. Hazard. Mater. 2020, 399, 123043. [CrossRef]

19. Zhang, Y.; Xu, M.; Liang, S.; Feng, Z.; Zhao, J. Mechanism of Persulfate Activation by Biochar for the Catalytic Degradation of Antibiotics: Synergistic Effects of Environmentally Persistent Free Radicals and the Defective Structure of Biochar. Sci. Total. Environ. 2021, 794, 148707. [CrossRef]

20. Moles, S.; Mosteo, R.; Gómez, J.; Szpunar, J.; Gozzo, S.; Castillo, J.R.; Ormad, M.P. Towards the Removal of Antibiotics Detected in Wastewaters in the POCTEFA Territory: Occurrence and $\mathrm{TiO}_{2}$ Photocatalytic Pilot-Scale Plant Performance. Water 2020, $12,1453$. [CrossRef]

21. Carvalho, I.T.; Santos, L. Antibiotics in the Aquatic Environments: A Review of the European Scenario. Environ. Int. 2016, 94, 736-757. [CrossRef] 
22. Danner, M.-C.; Robertson, A.; Behrends, V.; Reiss, J. Antibiotic Pollution in Surface Fresh Waters: Occurrence and Effects. Sci. Total Environ. 2019, 664, 793-804. [CrossRef]

23. Prestinaci, F.; Pezzotti, P.; Pantosti, A. Antimicrobial Resistance: A Global Multifaceted Phenomenon. Pathog. Glob. Health 2015, 109, 309-318. [CrossRef]

24. Wang, J.; Zhuan, R.; Chu, L. The Occurrence, Distribution and Degradation of Antibiotics by Ionizing Radiation: An Overview. Sci. Total Environ. 2019, 646, 1385-1397. [CrossRef] [PubMed]

25. Straub, J.O. Aquatic Environmental Risk Assessment for Human Use of the Old Antibiotic Sulfamethoxazole in Europe: Aquatic Environmental Risk Assessment for Human Sulfamethoxazole in Europe. Environ. Toxicol. Chem. 2016, 35, 767-779. [CrossRef] [PubMed]

26. Lykoudi, A.; Frontistis, Z.; Vakros, J.; Manariotis, I.D.; Mantzavinos, D. Degradation of Sulfamethoxazole with Persulfate Using Spent Coffee Grounds Biochar as Activator. J. Environ. Manag. 2020, 271, 111022. [CrossRef]

27. Schott, H.; Astigarrabia, E. Isoelectric Points of Some Sulfonamides: Determination by Microelectrophoresis and by Calculations Involving Acid-Base Strength. J. Pharm. Sci. 1988, 77, 918-920. [CrossRef] [PubMed]

28. Avisar, D.; Primor, O.; Gozlan, I.; Mamane, H. Sorption of Sulfonamides and Tetracyclines to Montmorillonite Clay. Water Air Soil Pollut. 2010, 209, 439-450. [CrossRef]

29. Xie, B.; Tang, X.; Ng, H.Y.; Deng, S.; Shi, X.; Song, W.; Huang, S.; Li, G.; Liang, H. Biological Sulfamethoxazole Degradation along with Anaerobically Digested Centrate Treatment by Immobilized Microalgal-Bacterial Consortium: Performance, Mechanism and Shifts in Bacterial and Microalgal Communities. Chem. Eng. J. 2020, 388, 124217. [CrossRef]

30. Wang, J.; Zhuan, R. Degradation of Antibiotics by Advanced Oxidation Processes: An Overview. Sci. Total. Environ. 2020, 701, 135023. [CrossRef]

31. Liu, S.; Peng, W.; Sun, H.; Wang, S. Physical and Chemical Activation of Reduced Graphene Oxide for Enhanced Adsorption and Catalytic Oxidation. Nanoscale 2014, 6, 766-771. [CrossRef]

32. Duan, X.; Sun, H.; Tade, M.; Wang, S. Metal-Free Activation of Persulfate by Cubic Mesoporous Carbons for Catalytic Oxidation via Radical and Nonradical Processes. Catal. Today 2018, 307, 140-146. [CrossRef]

33. Liu, X.; He, S.; Yang, Y.; Yao, B.; Tang, Y.; Luo, L.; Zhi, D.; Wan, Z.; Wang, L.; Zhou, Y. A Review on Percarbonate-Based Advanced Oxidation Processes for Remediation of Organic Compounds in Water. Environ. Res. 2021, 200, 111371. [CrossRef]

34. Fang, G.; Gao, J.; Liu, C.; Dionysiou, D.D.; Wang, Y.; Zhou, D. Key Role of Persistent Free Radicals in Hydrogen Peroxide Activation by Biochar: Implications to Organic Contaminant Degradation. Environ. Sci. Technol. 2014, 48, 1902-1910. [CrossRef] [PubMed]

35. Hung, C.-M.; Huang, C.-P.; Chen, C.-W.; Wu, C.-H.; Lin, Y.-L.; Dong, C.-D. Activation of Percarbonate by Water Treatment Sludge-Derived Biochar for the Remediation of PAH-Contaminated Sediments. Environ. Pollut. 2020, 265, 114914. [CrossRef]

36. Ntzoufra, P.; Vakros, J.; Frontistis, Z.; Tsatsos, S.; Kyriakou, G.; Kennou, S.; Manariotis, I.D.; Mantzavinos, D. Effect of Sodium Persulfate Treatment on the Physicochemical Properties and Catalytic Activity of Biochar Prepared from Spent Malt Rootlets. J. Environ. Chem. Eng. 2021, 9, 105071. [CrossRef]

37. Yin, R.; Guo, W.; Wang, H.; Du, J.; Wu, Q.; Chang, J.-S.; Ren, N. Singlet Oxygen-Dominated Peroxydisulfate Activation by SludgeDerived Biochar for Sulfamethoxazole Degradation through a Nonradical Oxidation Pathway: Performance and Mechanism. Chem. Eng. J. 2019, 357, 589-599. [CrossRef]

38. Li, F.; Duan, F.; Ji, W.; Gui, X. Biochar-Activated Persulfate for Organic Contaminants Removal: Efficiency, Mechanisms and Influencing Factors. Ecotoxicol. Environ. Saf. 2020, 198, 110653. [CrossRef] [PubMed]

39. Huong, P.T.; Jitae, K.; Al Tahtamouni, T.M.; Le Minh Tri, N.; Kim, H.-H.; Cho, K.H.; Lee, C. Novel Activation of Peroxymonosulfate by Biochar Derived from Rice Husk toward Oxidation of Organic Contaminants in Wastewater. J. Water Process. Eng. 2020, 33, 101037. [CrossRef]

40. Avramiotis, E.; Frontistis, Z.; Manariotis, I.D.; Vakros, J.; Mantzavinos, D. Oxidation of Sulfamethoxazole by Rice Husk BiocharActivated Persulfate. Catalysts 2021, 11, 850. [CrossRef]

41. Biswas, R.K.; Khan, P.; Mukherjee, S.; Mukhopadhyay, A.K.; Ghosh, J.; Muraleedharan, K. Study of Short Range Structure of Amorphous Silica from PDF Using Ag Radiation in Laboratory XRD System, RAMAN and NEXAFS. J. Non-Cryst. Solids 2018, 488, 1-9. [CrossRef]

42. Qian, L.; Guo, F.; Jia, X.; Zhan, Y.; Zhou, H.; Jiang, X.; Tao, C. Recent Development in the Synthesis of Agricultural and Forestry Biomass-Derived Porous Carbons for Supercapacitor Applications: A Review. Ionics 2020, 26, 3705-3723. [CrossRef]

43. Andrade, T.S.; Vakros, J.; Mantzavinos, D.; Lianos, P. Biochar Obtained by Carbonization of Spent Coffee Grounds and Its Application in the Construction of an Energy Storage Device. Chem. Eng. J. Adv. 2020, 4, 100061. [CrossRef]

44. Cho, D.-W.; Yoon, K.; Kwon, E.E.; Biswas, J.K.; Song, H. Fabrication of Magnetic Biochar as a Treatment Medium for As(V) via Pyrolysis of $\mathrm{FeCl}_{3}$-Pretreated Spent Coffee Ground. Environ. Pollut. 2017, 229, 942-949. [CrossRef]

45. Niu, H.; Liu, S.; Cai, Y.; Wu, F.; Zhao, X. MOF Derived Porous Carbon Supported Cu/Cu $\mathrm{Cu}_{2} \mathrm{O}$ Composite as High Performance Non-Noble Catalyst. Microporous Mesoporous Mater. 2016, 219, 48-53. [CrossRef]

46. Tran, T.N.; Pham, T.V.A.; Le, M.L.P.; Nguyen, T.P.T.; Tran, V.M. Synthesis of Amorphous Silica and Sulfonic Acid Functionalized Silica Used as Reinforced Phase for Polymer Electrolyte Membrane. Adv. Nat. Sci. Nanosci. Nanotechnol. 2013, $4,045007$. [CrossRef] 
47. Magioglou, E.; Frontistis, Z.; Vakros, J.; Manariotis, I.; Mantzavinos, D. Activation of Persulfate by Biochars from Valorized Olive Stones for the Degradation of Sulfamethoxazole. Catalysts 2019, 9, 419. [CrossRef]

48. Ntaflou, M.; Vakros, J. Transesterification activity of modified biochars from spent malt rootlets using triacetin. J. Clean. Prod. 2020, 259, 120931. [CrossRef]

49. Mrozik, W.; Minofar, B.; Thongsamer, T.; Wiriyaphong, N.; Khawkomol, S.; Plaimart, J.; Vakros, J.; Karapanagioti, H.; Vinitnantharat, S.; Werner, D. Valorisation of Agricultural Waste Derived Biochars in Aquaculture to Remove Organic Micropollutants from Water-Experimental Study and Molecular Dynamics Simulations. J. Environ. Manag. 2021, 300, 113717. [CrossRef] [PubMed]

50. Ha, H.T.; Minh, T.D.; Nguyet, H.M.; Sharma, A.K. Ampicillin Adsorption onto Amine-Functionalized Magnetic Graphene Oxide: Synthesis, Characterization and Removal Mechanism. Korean J. Chem. Eng. 2021, 38, 22-31. [CrossRef]

51. Yu, J.; Tang, L.; Pang, Y.; Zeng, G.; Wang, J.; Deng, Y.; Liu, Y.; Feng, H.; Chen, S.; Ren, X. Magnetic Nitrogen-Doped Sludge-Derived Biochar Catalysts for Persulfate Activation: Internal Electron Transfer Mechanism. Chem. Eng. J. 2019, 364, 146-159. [CrossRef]

52. Guo, Y.; Zeng, Z.; Liu, Y.; Huang, Z.; Cui, Y.; Yang, J. One-Pot Synthesis of Sulfur Doped Activated Carbon as a Superior Metal-Free Catalyst for the Adsorption and Catalytic Oxidation of Aqueous Organics. J. Mater. Chem. A 2018, 6, $4055-4067$. [CrossRef]

53. Martínez, L.; Bilski, P.; Chignell, C.F. Effect of Magnesium and Calcium Complexation on the Photochemical Properties of Norfloxacin. Photochem. Photobiol. 1996, 64, 911-917. [CrossRef]

54. Kłosińska-Szmurło, E.; Pluciński, F.A.; Grudzień, M.; Betlejewska-Kielak, K.; Biernacka, J.; Mazurek, A.P. Experimental and Theoretical Studies on the Molecular Properties of Ciprofloxacin, Norfloxacin, Pefloxacin, Sparfloxacin, and Gatifloxacin in Determining Bioavailability. J. Biol. Phys. 2014, 40, 335-345. [CrossRef] [PubMed]

55. Del Vecchio, P.; Haro, N.K.; Souza, F.S.; Marcílio, N.R.; Féris, L.A. Ampicillin Removal by Adsorption onto Activated Carbon: Kinetics, Equilibrium and Thermodynamics. Water Sci. Technol. 2019, 79, 2013-2021. [CrossRef] [PubMed]

56. Bourikas, K.; Vakros, J.; Kordulis, C.; Lycourghiotis, A. Potentiometric Mass Titrations: Experimental and Theoretical Establishment of a New Technique for Determining the Point of Zero Charge (PZC) of Metal (Hydr)Oxides. J. Phys. Chem. B 2003, 107, 9441-9451. [CrossRef]

57. Özkal, C.B.; Frontistis, Z.; Antonopoulou, M.; Konstantinou, I.; Mantzavinos, D.; Meriç, S. Removal of Antibiotics in a ParallelPlate Thin-Film-Photocatalytic Reactor: Process Modeling and Evolution of Transformation by-Products and Toxicity. J. Environ. Sci. 2017, 60, 114-122. [CrossRef] [PubMed] 